\title{
Learning Support System With Computer Assisted Instruction Method
}

\author{
${ }^{1}$ Mamed Rofendi, ${ }^{2}$ Amran Manalu \\ ${ }^{1}$ Manajemen Informatika, Universitas Imelda Medan, Sumatera utara \\ ${ }^{2}$ Tekinik Informatika, STMIK Pelita Nusantara, Sumatera Utara \\ Email: mamedfendi20@gmail.com ${ }^{1}$, amranmanalu12@gmail.com ${ }^{2}$
}

\begin{tabular}{ll}
\hline Keywords & $\begin{array}{l}\text { Abstract. Physics is a branch of science or natural science that has an important role in } \\
\text { advancing human thinking and thinking. Physics is the science of nature, which studies } \\
\text { the basic elements that make up the universe, the forces acting in it, and their } \\
\text { consequences covering a wide range from the subatomic particles that make up all matter } \\
\text { to the behavior of the universe as a single cosmos. Science or Natural Sciences (IPA) is } \\
\text { concerned with finding out about nature systematically, so that Science is not only the } \\
\text { mastery of a collection of knowledge in the form of facts, concepts, or principles but also } \\
\text { as a process of discovery. Through the high school level physical science learning } \\
\text { Physics Learning } \\
\text { application using the Computer Assisted Instruction (CAI) method, it is hoped that it can } \\
\text { increase the user knowledge in understanding straight motion kinematics material. }\end{array}$ \\
\hline
\end{tabular}

\section{INTRODUCTION}

The curriculum in the world of education is currently being directed at the unit level curriculum (KTSP), which is a curriculum that is oriented towards the competence of student abilities which includes knowledge, skills, attitudes, and values which are manifested in the habit of thinking and acting [1]. The learning process is the result of the synergy of the three main components of learning, namely students, teacher competence, and learning facilities. Current technological developments have caused many changes including in the world of education which gave birth to the concept of elearning, as an electronic learning medium that allows students to receive the lessons delivered more quickly [2]. Computer-Assisted Instruction (CAI) is the development of integrated information technology, namely communication, audio, video, and images packaged as multimedia. By applying the Computer Assisted Instruction (CAI) learning model to the concept of e-learning in every lesson in various ways, namely presenting material, interacting with students by displaying tutorials, either individually or in small groups. The learning media that is packaged in this computer program are expected to be more varied and innovative so that the teaching and learning process can run more effectively and efficiently [3], [4]. Where the interactions carried out by teachers and students are not only done face-to-face but also carried out with computer media as a learning tool that has been packaged as attractive as possible to help both teachers and students.

Physics is a branch of science or natural science that has an important role in advancing human thinking and thinking. Science is concerned with finding out about nature systematically, so that Science is not only the mastery of a collection of knowledge in the form of facts, concepts, or principles but also as a process of discovery. From year to year and until now, there are still many students who think that physics is a difficult, monotonous, boring, and even scary subject, so that students' interest in learning is very low to find out in more detail about these physics lessons [5]. The difficulty of understanding the formula in solving a problem is also one of the inhibiting factors for students in understanding the material. This is what requires that science learning be packaged as attractive as possible so that it doesn't seem monotonous and boring and easily understood by students. Learning science will be more meaningful and interesting for students if the teacher can convey and present problems that are easier to understand and closer to the daily lives of students. Therefore, teachers need to provide assistance or encouragement to students to make it easier to understand them.

\section{METHOD}

\subsection{Computer Assisted Instruction (CAI)}

Jurnal Info Sains : Informatikan dan Sains is licensed under a Creative Commons Attribution-Non Commercial 4.0 International License (CC BY-NC 4.0) 
Computer-Assisted Instruction (CAI) is a learning and teaching system that uses computer equipment as a tool together with its knowledge-based (basic knowledge). CAI is also a way of using computers directly in the teaching process as an alternative to books. Computer-Assisted Instruction (CAI) using computers becomes an integral part of a learning system, students are generally involved in two-way interaction with computers through a terminal. CAI has an impact on education. In handling large amounts and various kinds of information about various types and types and classifications of students, educational institutions need skills in the field of information (storage and retrieval) [5], [6].

The format for presenting messages and information in Computer Assisted Instruction (CAI) consists of programmed tutorials, intelligence tutorials, drill and practice, and simulations. Programmed tutorials are a set of both static and dynamic impressions that have been programmed in advance. In sequence, a small set of information is displayed which is followed by a question. Students' answers were analyzed by computer and based on the results of that analysis the appropriate feedback. Other auxiliary media are usually combined for programmatic tutorial forms, such as printbased reading assignments, group activities, laboratory experiments, exercise activities, simulations, and interactive video discs. The benefits of programmatic tutorials will be seen when using branched and interactive computer technology capabilities [6], [7].

Computer-Assisted Instruction (CAI)-assisted learning has been developed recently and has proven its benefits to assist teachers in teaching and assisting students in learning. Computers can simultaneously help tens of students and in the future, it is hoped that they can help thousands of students at once. So it can be concluded that Computer Assisted Instruction (CAI) is one of the teaching methods used to assist teachers in teaching material interactively in a tutorial program using a computer application. In delivering teaching, Computer Assisted Instruction (CAI) can control various processes, such as presenting material to users to learn, giving questions and problems to answer, and providing an assessment of learning outcomes to users [8].

Computer-Assisted Instruction (CAI) is developed through the Instruction and Operating Conditions program such as a theoretical guide. So that students must be given sufficient freedom to control their learning methods. According to the journal Harvei Desmon Hutahaean, Computer Assisted Instruction (CAI) lessons have the following characteristics:

1) Small steps

2) Respond clearly

3) Quick feedback

4) Leap yourself

\subsection{Computer Assisted Instruction (CAI) Models}

There are four types of Computer Assisted Instruction (CAI) learning models, namely

1) Tutorial Model

Tutorials aim to convey or explain certain material where the computer delivers material, asks questions, and provides feedback according to student answers. In presenting the material, tutorials can be divided into linear tutorials and branched tutorials. Linear tutorials present one topic to the next in an order that has been determined by programming so that students cannot choose learning material according to their wishes and abilities. Thus, each student learns the same material, linear tutorials ignore differences in individual abilities. On the other hand, in tutorial branching, individual differences are considered by giving students the freedom to study material according to their wishes and abilities[9].

2) Model Drill And Practice

The drill and practice model is a model in learning by training students in the learning materials that have been given. With constant practice, it will become embedded and then become a habit. In addition to instilling habits, this model can also increase speed, accuracy, perfection in doing something and can also be used as a way to repeat the material that has been presented [10]. The general characteristics of the Drill and Practice Model are:

Jurnal Info Sains : Informatikan dan Sains is licensed under a Creative Commons Attribution-Non Commercial 4.0 International License (CC BY-NC 4.0) 
a) There is a presentation of problems in the form of practice questions at a certain level

b) Students work on the questions

c) Any feedback

The purpose of learning through the CAI drill and practice model is basically to provide exercise conditions and recall information from learning materials or certain information within a predetermined time.

3) Simulation Model

Simulation is used to demonstrate something so that students feel like they are in a real situation. Simulation is widely used in dangerous learning material or material that is difficult to understand [11].

4) Model Games

This game model is developed based on "fun learning", where students will be faced with several instructions and game rules. In this game-based learning model, games will be designed to generate excitement in students to increase the possibility of storing concepts, knowledge, or skills that are expected to be obtained from the game longer.

The purpose of Instructional games is to provide an atmosphere (environment) that provides learning facilities that enhance students' abilities. Instructional games do not need to mimic reality but can have characters that provide a fun challenge for students [12].

\section{RESULTS AND DISCUSSION}

\subsection{Analysis of Physics Teaching Materials}

The topics that will be discussed in the physics science learning application of straight motion kinematics include Motion, Distance and Displacement, Speed and Velocity, Acceleration and Progress, Regular Straight Motion, Regular Changing Straight Motion, and Free Fall Motion.

a) Motion

The basic competencies of learning that must be mastered by students on this topic are that students are expected to be able to know and describe the definition of motion in the straight motion kinematics material.

Based on the conclusion above, in this topic, the only tutorial is presented to introduce the definition of motion.

b) Distance and Displacement

The basic competencies of learning that students must master on this topic are that students are expected to be able to know and describe the definitions of distance and displacement, be able to work on practice questions given by the teacher, and complete group assignments on the straight motion kinematics material. Based on the above conclusions, this discussion topic requires tutorials and practice questions to help students understand the topic.

c) Speed and Speed

The basic competencies of learning that students must master on this topic are that students are expected to be able to know and describe the definitions of speed and speed, be able to work on practice questions given by the teacher, and complete group assignments on the straight motion kinematics material. Based on the above conclusions, this discussion topic requires tutorials and practice questions to help students understand the topic.

d) Acceleration and Acceleration

As for the basic competencies of learning that students must master on this topic, students are expected to be able to know and describe the definition of Acceleration and Progress, be able to work on practice questions given by the teacher, and complete group assignments on the straight motion kinematics material. Based on the above conclusions, this discussion topic requires tutorials and practice questions to help students understand the topic. As well as games which are a collection of questions or quizzes from the material of motion, distance and displacement, speed and velocity as well as acceleration and speed.

Jurnal Info Sains : Informatikan dan Sains is licensed under a Creative Commons Attribution-Non Commercial 4.0 International License (CC BY-NC 4.0) 
e) Regular Straight Motion (GLB)

The basic competencies of learning that students must master on this topic are that students are expected to be able to know and describe the definition of Regular Straight Motion (GLB), be able to work on practice questions given by the teacher, and complete group assignments on the kinematics of straight motion material. Based on the above conclusions, this discussion topic requires tutorials and practice questions to help students understand the topic.

f) Motion Straight Changed Regularly (GLBB)

The basic competencies of learning that students must master on this topic are that students are expected to be able to know and describe the definition of Regularly Changing Straight Motion (GLBB), be able to work on practice questions given by the teacher, and complete group assignments and display simulations aimed at making students more understand the concept of straight-changing regular motion. Based on the above conclusions, this discussion topic requires tutorials and practice questions to help students understand the topic. A collection of games which is a collection of questions or quizzes from Regular Straight Motion and Regularly Changing Straight Motion. As well as a simulation to explain the actual use of regular motion.

g) Free Fall Movement

The basic competencies of learning that students must master on this topic are that students are expected to be able to know and describe the definition of Free Fall Motion (GJB), be able to work on practice questions given by the teacher, and complete group assignments on the straight motion kinematics material. Based on the above conclusions, this discussion topic requires tutorials and practice questions to help students understand the topic. As well as games which are a collection of questions or quizzes from the entire discussion topic on straight motion kinematics material.

\subsection{Application of the Computer Assisted Instruction (CAI) Method}

Based on the description and analysis of the physics book above, learning media was prepared as a learning aid for students using the Computer Assisted Instruction (CAI) method. The design description of the physics science learning application is as follows:

a) Tutorial Model

In this tutorial model, there are 7 tutorials in each material that contain definitions and formulas used in each discussion topic of straight motion kinematics. This tutorial is on the topic of discussion about Motion, Distance and Displacement, Speed and Speed, Acceleration and Progress, Regular Straight Motion, Regular Changing Straight Motion, and Free Fall Motion.

b) Model Drill And Practice

In this model, there are 6 drills and practice, namely in each topic discussion of straight motion kinematics material. The total number of practice questions is 12 questions, that is, there are 2 practice questions for each material.

c) Simulation Model

There is only 1 simulation model in learning physics science, which is a combination of several discussion topics. This simulation is also presented after the material of Straight Motion Changes Regularly because this simulation has covered several discussion topics on the use of the formula. The simulation offered in this physics science learning application is a simulation of a moving car with the addition of a multimedia atmosphere and sound in it so that physics science learning is more interesting and understandable through this simulation model.

d) Model Games

In this model, quiz questions are divided into 3 parts, namely:

1) Taken from 4 discussion topics, namely discussion topics 1, 2, 3, and 4 . As for its use after completing the 4th material with a total of 8 questions.

2) Taken from 2 discussion topics, namely discussion topics 5 and 6 . As for its use after completing the 6th material with a total of 5 questions.

Jurnal Info Sains : Informatikan dan Sains is licensed under a Creative Commons Attribution-Non Commercial 4.0 International License (CC BY-NC 4.0) 


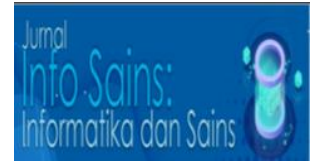

3) Taken from the overall discussion topic of straight motion kinematics material. As for its use after the 7th discussion topic with a total of 20 questions.

\subsection{Algorithm and Implementation}

An algorithm is a logical arrangement in the form of steps or systematic ways to solve a problem or to achieve a certain goal. The true value must be able to determine right or wrong.

a) Teacher Login Algorithm

This algorithm is the first step that the teacher takes before using this learning application. The process is as follows:

1. Input: Name, Password

2. Output: Material Topics

3. Process:

If name $=$ "admin" and password $=$ "12345" then

Show Material Topics

Else

Return to Home

End If

b) Algorithm Tutorial

This algorithm is a step-by-step method for displaying the choice of topic for discussion material that the teacher will choose to update it. The process is as follows:

1. Input: Title of Material, Content of Material

2. Output: Material

3. Process:

Category title $\leftarrow$ Title

Detailed Information $\leftarrow$ Contents

Save Data

c) Drill and Practice Algorithm

This algorithm is a step-by-step method for displaying Sample Problems, Solutions, and Practice Questions which the teacher can update at any time. The process is as follows:

1. Input: Example Problems Kd_Soal1 to Kd_Soal7, Exercises Kd_Soal1 to Kd_Soal7, Answers Kd_Soal1 to Kd_Soal7

2. Output: Problem

3. Process:

Problem Category $\leftarrow$ Sample Questions and Practice Questions

Question Details $\leftarrow$ Content and Resolution

Save Data

d) Games Algorithm

This algorithm is a step for displaying quiz questions and score results which can be updated at any time by the teacher. The process is as follows:

1. Input: Quiz Questions Kd_Soal1 to Kd_Soal4

2. Output: Answer

3. Process:

Question Category $\leftarrow$ Quiz

Games Details $\leftarrow$ Fill in the quiz answers and scores

e) Simulation Algorithms

This algorithm is the steps to display the simulation of the discussion topic of regular changing straight motion. The process is as follows:

1. Input: Value

2. Output: GLBB simulation

3. Process:

Input Value $\leftarrow$ Simulation

Jurnal Info Sains : Informatikan dan Sains is licensed under a Creative Commons Attribution-Non Commercial 4.0 International License (CC BY-NC 4.0) 


\author{
Simulation Details $\leftarrow$ GLBB Simulation
}

\title{
4. CONCLUSION
}

In presenting the application theory of learning physics subjects regarding the kinematics of straight motion. The discussion topics are about motion, distance and displacement, speed and velocity, acceleration and acceleration, regular straight motion, regular changing straight motion and free fall motion and presenting multimedia nuances in which sound and animation are in accordance with the topic of discussion. Applying the Computer Assisted Instruction method or computer-based learning can be implemented in high school level physics learning applications where this application can be used individually and this application consists of tutorials, drill and practice, games and simulations. To design this learning application, it is done by designing the display page first then applying it to Macromedia Flash Professional 8 until the final stage can be used by the user. In this physics learning application, it consists of several forms, namely the Home Form, the Main Menu Form, the Login Form, the Tutorial Form, the Drill and Practice Form, the Games Form, the Simulation Form, the Score Form and the About Me Form.

\section{REFERENCES}

[1] J. Simarmata et al., "Applying the learning multimedia applications for completion of linear equations with subscription methods," Int. J. Eng. Technol., vol. 7, no. 3.4 Special Issue 4, 2018.

[2] R. Ysquierdo, "The effects of computer-assisted language learning on English language proficiency," 2018.

[3] NCT03469154, "Sustainable Solutions for Paediatric Basic Life Support Training in Day Care Centres," https://clinicaltrials.gov/show/NCT03469154, 2018.

[4] E. F. Melcer, "Learning with the body: Understanding the design space of embodied educational technology.," Diss. Abstr. Int. Sect. B Sci. Eng., vol. 79, no. 10-B(E), 2018.

[5] A. Sukariyani, "APLIKASI PEMBELAJARAN HIDROGRAFI MENGGUNAKAN METODE COMPUTER ASSISTED INSTRUCTION (CAI),” Pelita Inform., vol. 6, 2018.

[6] N. Maulida, H. Anra, and H. S. Pratiwi, "Aplikasi Pembelajaran Interaktif Pengenalan Hewan pada Anak Usia Dini," J. Sist. dan Teknol. Inf., vol. 6, no. 1, 2018, doi: 10.26418/justin.v6i1.23726.

[7] M. NUR IKA FITRIA and S. SULANDJARI, "PENGEMBANGAN MEDIA PEMBELAJARAN PEMBUATAN POLA DASAR BUSANA WANITA BERBASIS COMPUTER ASSISTED INSTRUCTION (CAI) MODEL TUTORIAL DI SMK NEGERI 1 SOOKO MOJOKERTO,” J. Tata Busana, vol. 7, no. 3, 2018.

[8] S. Hu et al., "Weakly supervised deep learning for covid-19 infection detection and classification from ct images," IEEE Access, vol. 8, pp. 118869-118883, 2020.

[9] Z. Ge, "Process Data Analytics via Probabilistic Latent Variable Models: A Tutorial Review," Ind. Eng. Chem. Res., vol. 57, no. 38, 2018, doi: 10.1021/acs.iecr.8b02913.

[10] R. T. Jurnal, "PENGEMBANGAN MODEL PEMBELAJARAN BERBASIS TUTORIAL BAGI MAHASISWA TEKNIK MESIN STT PLN," Power Plant, vol. 5, no. 1, 2018, doi: 10.33322/powerplant.v5i1.111.

[11] U. Rahayu and A. Sapriati, "Open educational resources based online tutorial model for developing critical thinking of higher Distance Education Students," Turkish Online J. Distance Educ., vol. 19, no. 4, 2018, doi: 10.17718/tojde.471914.

[12] R. A. Kievit et al., "Developmental cognitive neuroscience using latent change score models: A tutorial and applications," Developmental Cognitive Neuroscience, vol. 33. 2018, doi: 10.1016/j.den.2017.11.007.

Jurnal Info Sains : Informatikan dan Sains is licensed under a Creative Commons Attribution-Non Commercial 4.0 International License (CC BY-NC 4.0) 